\title{
Branched Chain Amino Acid Oxidation in Cultured Rat Skeletal Muscle Cells
}

\author{
SELECTIVE INHIBITION BY CLOFIBRIC ACID
}

\author{
William M. Pardridge, Delia Casanello-Ertl, and \\ Luiza Duducgian-Vartavarian, Department of Medicine, Division of \\ Endocrinology/Metabolism, University of California Los Angeles School of \\ Medicine, Los Angeles, California 90024
}

\begin{abstract}
A в S T R A C T Leucine metabolism in skeletal muscle is linked to protein turnover. Since clofibrate is known both to cause myopathy and to decrease muscle protein content, the present investigations were designed to examine the effects of acute clofibrate treatment on leucine oxidation. Rat skeletal muscle cells in tissue culture were used in these studies because cultivated skeletal muscle cells, like muscle in vivo, have been shown to actively utilize branched chain amino acids and to produce alanine. The conversion of $\left[1-{ }^{14} \mathrm{C}\right]$ leucine to ${ }^{14} \mathrm{CO}_{2}$ or to the $\left[1-{ }^{14} \mathrm{C}\right] \mathrm{keto}$-acid of leucine $(\alpha$-keto-isocaproate) was linear for at least $2 \mathrm{~h}$ of incubation; the production of ${ }^{14} \mathrm{CO}_{2}$ from $\left[1-{ }^{14} \mathrm{C}\right]$ leucine was saturable with a $K_{\mathrm{m}}=6.3 \mathrm{mM}$ and a maximum oxidation rate $\left(\mathrm{V}_{\max }\right)=31 \mathrm{nmol} / \mathrm{mg}$ protein per $120 \mathrm{~min}$. Clofibric acid selectively inhibited the oxidation of $\left[1-{ }^{14} \mathrm{C}\right]$ leucine $\left(K_{\mathrm{i}}=0.85 \mathrm{mM}\right)$ and $\left[\mathrm{U}-{ }^{14} \mathrm{C}\right]$ isoleucine, but had no effect on the oxidation of $\left[\mathrm{U}-{ }^{14} \mathrm{C}\right]$ glutamate, -alanine, -lactate, or -palmitate. The inhibition of $\left[1-{ }^{14} \mathrm{C}\right]$ leucine oxidation by clofibrate was also observed in the rat quarter-diaphragm preparation. Clofibrate primarily inhibited the production of ${ }^{14} \mathrm{CO}_{2}$ and had relatively little effect on the production of $\left[1-{ }^{14} \mathrm{C}\right]-$ keto-acid of leucine. A physiological concentration$3.0 \mathrm{~g} / 100 \mathrm{ml}$ - of albumin, which actively binds clofibric acid, inhibited but did not abolish the effects of a 2-m M concentration of clofibric acid on leucine oxidation. Clofibrate treatment stimulated the net consumption of pyruvate, and inhibited the net production of alanine. The drug also increased the cytosolic NADH/ $\mathrm{NAD}^{+}$ratio as reflected by an increase in the lactate/ pyruvate ratio, in association with a decrease in cell
\end{abstract}

Dr. Pardridge was the recipient of Clinical Investigator Award AM-00409.

Received for publication 19 October 1979 and in revised form 7 March 1980. aspartate levels. The changes in pyruvate metabolism and cell redox state induced by the drug were delayed compared with the nearly immediate inhibition of leucine oxidation. These studies suggest that clofibric acid, in concentrations that approximate high therapeutic levels of the drug, selectively inhibits branched chain amino acid oxidation, possibly at the level of the branched chain keto-acid dehydrogenase.

\section{INTRODUCTION}

Clofibrate ${ }^{1}$ is known to cause myopathy in both man (1) and experimental animals (2). Recent studies with rats suggest that the drug may impair protein turnover in skeletal muscle because clofibrate-treated animals have shown diminished total muscle protein (3). Protein turnover in skeletal muscle is believed to be linked to the metabolism of leucine (4), a branched chain amino acid. Therefore, if clofibrate does induce myopathic changes by altering protein turnover in skeletal muscle, one possible mechanism for these events might be a drug-induced alteration in leucine metabolism in muscle. Another observation that suggests a possible linkage between clofibrate and branched chain amino acid metabolism in skeletal muscle is the marked hypoalaninemia associated with therapeutic doses of the drug (5). Skeletal muscle is the major site of alanine production (6-9), and alanine synthesis in muscle cells is coupled to the transamination of the branched chain amino acids $(10,11)$. Therefore, a putative inhibition of branched chain amino acid utilization by clofibrate would be expected to decrease the production of alanine.

The effects of clofibrate treatment on leucine oxida-

\footnotetext{
${ }^{1}$ Clofibrate (Atromid-S) is the ethyl ester of the active compound clofibric acid, or $p$-chlorophenoxyisobutyric acid.
} 
tion in isolated rat skeletal muscle cells in tissue culture are described in this paper. Similar to intact skeletal muscle (6-11), cultivated skeletal muscle cells have been shown in previous studies (12-14) both to actively use the branched chain amino acids and to produce alanine.

\section{METHODS}

All tissue culture supplies, enzymes, and reagents were obtained as previously described (12). All isotopes were purchased from New England Nuclear, Boston, Mass. Clofibric acid was obtained from Aldrich Chemical Co. Inc., Milwaukee, Wis.

The maintenance of stock cultures of cells of the $\mathrm{L}_{6}$ myogenic line (15) and the preparation of 10-d-old myotubes (on 60- or 100-mm petri dishes) were exactly as described previously (12), except that the cells were grown in a humidified atmosphere of $95 \%$ air:5\% $\mathrm{CO}_{2}$, and the medium bicarbonate concentration was reduced by one-half, to $22 \mathrm{mM}$. Experimental incubations for the determination of metabolite levels were initiated by discarding old medium and adding to 100-mm dishes $3 \mathrm{ml}$ of Dulbecco's modified Eagle's medium containing no fetal calf serum and adjusted to $0.4 \mathrm{mM}$ pyruvate, $2.5 \mathrm{mM}$ lactate, and $0.5 \mathrm{mM}$ glutamine; the levels of other nutrients in this medium have been listed previously (12). Dishes with or without clofibric acid $(2 \mathrm{mM})$ were incubated up to $4 \mathrm{~h}$. At the end of the incubation, neutralized perchloric acid extracts of cold-washed cells and of medium were prepared as reported previously, with special storage precaution under acid $\mathrm{pH}$ for the $\alpha$-keto-acids, pyruvate and $\alpha$-ketoglutarate $(12,16)$.

All metabolite levels were determined in duplicate with enzymatic fluorometric or spectrophotometric methods as reported previously $(12,16)$. Clofibrate levels in the medium were determined spectrophotometrically (17).

$\mathrm{CO}_{2}$ collection studies were performed with 10-d-old myotube preparations grown on $60-\mathrm{mm}$ dishes. The incubation was started by discarding old medium and adding 2.5 $\mathrm{ml}$ of Dulbecco's modified Eagle's medium; this medium contained no serum and was adjusted to $0.1 \mathrm{mM}$ pyruvate, $0.4 \mathrm{mM}$ glutamine, and $0.1 \mu \mathrm{Ci} / \mathrm{ml}$ of ${ }^{14} \mathrm{C}$-metabolite. The $60-\mathrm{mm}$ dishes without lids were placed in small crystallizing dishes, which were tightly capped with a rubber stopper that encased a serum stopper and filter paper-lined plastic cup (Kontes Co., Vineland, N. J.). The dishes were gassed for about 1 min with $95 \% \mathrm{O}_{2}: 5 \% \mathrm{CO}_{2}$ and incubated at $37^{\circ} \mathrm{C}$ for up to $2 \mathrm{~h}$ with slow agitation. At the end of the incubation, $0.4 \mathrm{ml}$ NCS base (Amersham Corp., Arlington Heights, Ill.) was added to the cup, the medium was acidified by injection of $0.5 \mathrm{ml}$ of $1 \mathrm{~N}$ perchloric acid, and $\mathrm{CO}_{2}$ was collected over the next $60 \mathrm{~min}$. The cup containing labeled $\mathrm{CO}_{2}$ was placed in a glass vial for liquid scintillation counting. The $\left[1-{ }^{14} \mathrm{C}\right]-$ keto-acid of leucine ( $\alpha$-keto-isocaproate) remaining in the medium was measured by removing $0.5 \mathrm{ml}$ of the acidified medium to a $25-\mathrm{ml}$ flask. This flask was stoppered and 0.5 $\mathrm{ml}$ of $15 \%$ hydrogen peroxide was added, and the labeled $\mathrm{CO}_{2}$ produced by peroxide treatment was collected as described above. Odessey and Goldberg (18) have shown that peroxide treatment quantitatively decarboxylates the branched chain keto-acids. The total $\left[1{ }^{14} \mathrm{C}\right]$ leucine transaminated equaled the ${ }^{14} \mathrm{CO}_{2}$ fraction plus the $\left[1{ }^{14} \mathrm{C}\right]$ keto-isocaproate fraction (18).

Rates of $\mathrm{CO}_{2}$ or keto-acid formation (nanomoles per milligram protein per minute) were calculated by dividing incorporation rates (disintegrations per minute per milligram protein per minute) by medium specific activity (disintegra- tions per minute per nanomole). Since the leucine level in tissue culture medium is high $-0.8 \mathrm{mM}$-it is assumed that the specific activity of leucine (and the keto-acid of leucine) in the cell is equal to the specific activity of leucine in the medium. Hutson et al. (19) have shown that these relationships hold for the perfused hindlimb when the medium leucine level is $0.5 \mathrm{mM}$. The effects of clofibric acid $(2 \mathrm{mM})$ on the oxidation of $\left[1-{ }^{-14} \mathrm{C}\right]$ leucine were also investigated in a few studies in the rat quarter-diaphragm preparation. Diaphragms were obtained from 300-g Sprague-Dawley fed rats and incubated in a Krebs-Ringer buffer gassed with $95 \% \quad \mathrm{O}_{2}: 5 \%$ $\mathrm{CO}_{2}$ at $37^{\circ} \mathrm{C}$. The final $2-\mathrm{ml}$ incubation media contained $11 \mathrm{mM}$ glucose, $0.1 \mathrm{mM}$ L-leucine, and $0.1 \mu \mathrm{Ci} / \mathrm{ml}$ of $\left[1-{ }^{-14} \mathrm{C}\right]$ leucine.

Cultures were shown to be free of mycoplasma contamination in our laboratory by two independent methods $(20,21)$. Data are reported as mean $\pm S E M$. Quadruplicate dishes were studied at all time points for $\mathrm{CO}_{2}$ collection studies and triplicate dishes were used for metabolite measurements. Background disintegrations per minute in all $\mathrm{CO}_{2}$ collection studies were determined by incubating dishes without cells containing medium labeled with the ${ }^{14} \mathrm{C}$-compound. Statistical significance was assessed using $t$ test.

\section{RESULTS}

As skeletal muscle cells in tissue culture have not been heretofore used as a model system for the investigation of amino acid oxidation, a total of $17 \mathrm{U}-{ }^{14} \mathrm{C}$-amino acids were assayed for rates of $\mathrm{CO}_{2}$ production during a $2-\mathrm{h}$ incubation (Table I). In general, the amino acids found to be converted to $\mathrm{CO}_{2}$ in diaphragm-e.g., the branched chain amino acids alanine, glutamate, and aspartate (22) - are the same amino acids metabolized

\section{TABLE I}

Oxidation of Amino Acids, Lactate, and Glucose by $L_{6}$ Skeletal Muscle Cells in Tissue Culture and the Effect of Clofibric Acid (2 mM)

\begin{tabular}{|c|c|c|}
\hline \multirow[b]{2}{*}{ Substrate (m.M) } & \multicolumn{2}{|c|}{$\mathrm{CO}_{2}$ production $*$} \\
\hline & Control & Clofibric acid \\
\hline & \multicolumn{2}{|c|}{ nmollmg protein $/ 120 \mathrm{~min}$} \\
\hline$\left[\mathrm{U}-{ }^{14} \mathrm{C}\right]$ Lactate $(1.0)$ & $9.0 \pm 1.2$ & $8.7 \pm 1.0$ \\
\hline$\left[\mathrm{U}-{ }^{14} \mathrm{C}\right] \mathrm{Glucose}(5.0)$ & $8.8 \pm 2.0$ & $7.5 \pm 0.9$ \\
\hline$\left[\mathrm{U}-{ }^{14} \mathrm{C}\right]$ Glutamate $(0.4)$ & $10.7 \pm 1.0$ & $9.6 \pm 0.9$ \\
\hline$\left[\mathrm{U}-{ }^{14} \mathrm{C}\right]$ Aspartate $(0.4)$ & $7.3 \pm 1.0$ & - \\
\hline$\left[1{ }^{14} \mathrm{C}\right]$ Leucine $(0.8)$ & $5.2 \pm 0.2$ & $1.4 \pm 0.2 \ddagger$ \\
\hline$\left[\mathrm{U}-{ }^{14} \mathrm{C}\right]$ Glutamine $(0.4)$ & $3.3 \pm 1.0$ & - \\
\hline$\left[\mathrm{U}-{ }^{14} \mathrm{C}\right]$ Alanine $(0.04)$ & $2.8 \pm 0.3$ & $3.1 \pm 0.4$ \\
\hline [U- $\left.{ }^{14} \mathrm{C}\right]$ Isoleucine $(0.8)$ & $1.3 \pm 0.2$ & $0.30 \pm 0.04 \ddagger$ \\
\hline [U-14C]Leucine $(0.8)$ & $1.1 \pm 0.2$ & - \\
\hline$\left[\mathrm{U}-{ }^{14} \mathrm{C}\right]$ Arginine $(0.4)$ & $0.6 \pm 0.1$ & - \\
\hline [U-14C]Valine (0.8) & $0.3 \pm 0.1$ & - \\
\hline
\end{tabular}

* Data are mean \pm SEM. The following $\mathrm{U}-{ }^{14} \mathrm{C}$-amino acids at a concentration of $0.4-0.8 \mathrm{mII}$ produced immeasurably low amounts of ${ }^{14} \mathrm{CO}_{2}(<0.1 \mathrm{nmol} / \mathrm{mg}$ protein $/ 120 \mathrm{~min})$ : histidine, phenylalanine, tyrosine, tryptophan, lysine, threonine, proline, serine, and glycine.

$\ddagger P<0.005$ difference from control. 


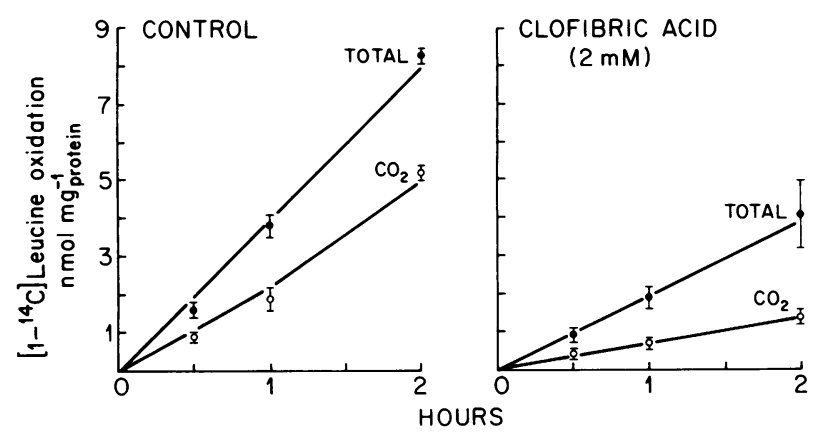

Figure 1 Rates of total metabolism of $\left[1-{ }^{14} \mathrm{C}\right]$ leucine and of leucine oxidation to ${ }^{14} \mathrm{CO}_{2}$ are linear with time for at least $2 \mathrm{~h}$ of incubation in both control and clofibrate-treated cells. Total metabolism of $\left[1-{ }^{14} \mathrm{C}\right]$ leucine $=\left[1-{ }^{14} \mathrm{C}\right]$ keto-acid formation $+{ }^{14} \mathrm{CO}_{2}$ formation. The inhibition in total $\left[1-{ }^{14} \mathrm{C}\right]$ leucine metabolism is due essentially to an inhibition in ${ }^{14} \mathrm{CO}_{2}$ formation, which suggests clofibrate inhibits leucine $\alpha$ decarboxylation, not transamination. Data are mean $\pm S E M$ $(n=4)$.

by $\mathrm{L}_{6}$ muscle cells. In addition, $\mathrm{L}_{6}$ cells oxidize glutamine as a carbon source (12 and Table I). Although $\mathrm{CO}_{2}$ production studies using $\left[{ }^{14} \mathrm{C}\right]$ glutamine in diaphragm have apparently not been reported, we have recently observed a linear rate of $\mathrm{CO}_{2}$ production from $\left[\mathrm{U}-{ }^{14} \mathrm{C}\right]$ glutamine in rat diaphragm for at least $2 \mathrm{~h}$ of incubation. $^{2}$

The oxidation of several ${ }^{14} \mathrm{C}$-amino acids, $\left[{ }^{14} \mathrm{C}\right] \mathrm{glu}$ cose, and $\left[{ }^{14} \mathrm{C}\right]$ lactate was measured in the presence or absence of a $2-\mathrm{mM}$ concentration of clofibrate. As shown in Table I, the oxidation of the branched chain amino acids was selectively inhibited by clofibrate. In addition, the effect of $2 \mathrm{mM}$ clofibric acid on the oxidation of $\left[\mathrm{U}-{ }^{14} \mathrm{C}\right]$ palmitate $(0.1 \mu \mathrm{Ci} / \mathrm{ml})$ was measured. In these experiments, the medium was supplemented with $10 \%$ fetal calf serum, which maintained the labeled free fatty acid in aqueous solution. The rate of ${ }^{14} \mathrm{CO}_{2}$ production was $461 \pm 128$ and $529 \pm 78 \mathrm{dpm} / \mathrm{mg}$ protein per $120 \mathrm{~min}$ in the absence or presence of $2 \mathrm{mM}$ clofibric acid; this difference was not statistically significant $(P<0.25)$.

The clofibrate inhibition of $\left[1-{ }^{14} \mathrm{C}\right]$ leucine oxidation was detectable as early as $30 \mathrm{~min}$ of incubation and persisted for at least $2 \mathrm{~h}$ (Fig. 1). The total leucine transaminated was inhibited an average of $52 \%$ by $2 \mathrm{mM}$ clofibrate, due primarily to a $78 \%$ inhibition in the ${ }^{14} \mathrm{CO}_{2}$ fraction. In the absence of the drug, $65 \%$ of the total $\left[1-{ }^{14} \mathrm{C}\right]$ leucine transaminated was recovered in the $\mathrm{CO}_{2}$ fraction, whereas only $31 \%$ of the radioactivity was in the $\mathrm{CO}_{2}$ fraction in the presence of clofibrate. The inhibition of $\left[1-{ }^{14} \mathrm{C}\right]$ leucine oxidation by clofibrate was also observed in diaphragm muscle tissue obtained from adult rats (Fig. 2), as well as in

${ }^{2}$ Pardridge, W. M., and M. B. Davidson. Unpublished results.

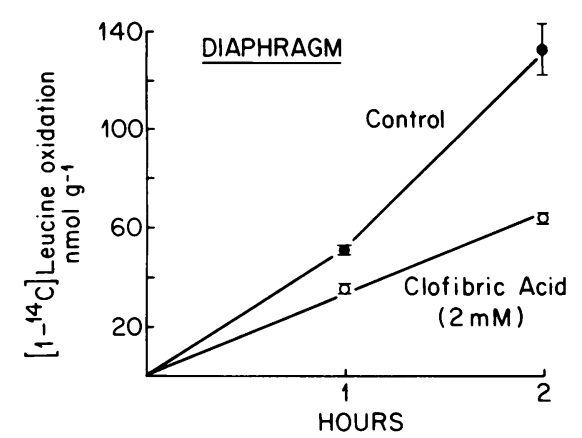

FIgure 2 Rates of oxidation to ${ }^{14} \mathrm{CO}_{2}$ from $\left[1-{ }^{14} \mathrm{C}\right]$ leucine are nearly linear for at least $2 \mathrm{~h}$ in the rat quarter-diaphragm preparation. The presence of clofibric acid $(2 \mathrm{mM})$ results in a $52 \%$ inhibition in $\mathrm{CO}_{2}$ formation at $2 \mathrm{~h}$. Data are mean $\pm \mathrm{SEM}$ $(n=3)$.

skeletal muscle cells obtained from adult rats and grown in primary tissue culture. ${ }^{3}$

With increasing leucine concentrations, leucine oxidation was saturable (Fig. 3); a double reciprocal plot (data not shown) of the data in Fig. 3 was linear ( $r$ $=0.98)$ and indicated that the $K_{\mathrm{m}}=6.3 \mathrm{mM}$ and maximal oxidation rate $\left(\mathrm{V}_{\max }\right)^{4}=31 \mathrm{nmol} / \mathrm{mg}$ protein per 120 min. Levels of leucine up to $10 \mathrm{mM}$ did not overcome the inhibitory effects of $1.5 \mathrm{mM}$ clofibrate, i.e., the $\mathrm{V}_{\text {max }}$ was lowered with relatively little change in $K_{\mathrm{m}}$ (Fig. 3). Additional experiments in which the clofibrate concentration was varied demonstrated that the clofibrate level at $50 \%$ inhibition $\left(K_{\mathrm{i}}\right)$ was $0.85 \mathrm{mM}$ (Fig. 4),

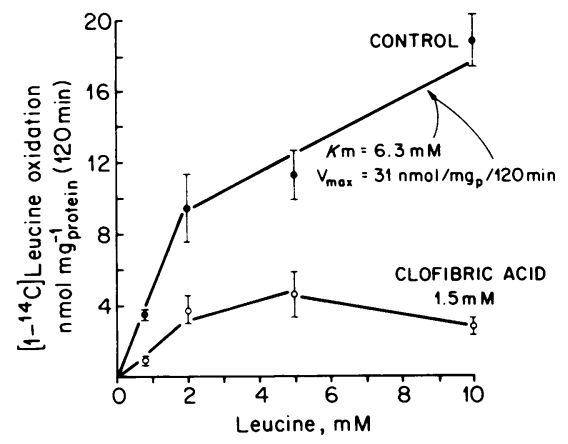

Figure 3 The conversion of $\left[1-{ }^{14} \mathrm{C}\right]$ leucine to ${ }^{14} \mathrm{CO}_{2}$ during a 2 -h incubation period is saturable. The kinetic constants $\left(K_{\mathrm{m}}, \mathrm{V}_{\max }\right)$ of the control cells were calculated from a double reciprocal plot (data not shown) which was linear $(r=0.98)$. Clofibrate treatment $\left(1.5 \mathrm{mM}\right.$ ) lowered the $\mathrm{V}_{\max }$ (maximal oxidation rate) with little effect on $K_{m}$ (half-saturation constant), which is consistent with a noncompetitive inhibition mechanism. Data are mean $\pm \operatorname{SEM}(n=4)$.

\footnotetext{
${ }^{3}$ Pardridge, W. M., L. Duducgian-Vartavarian, D. Casanello-Ertl, M. R. Jones, and J. D. Kopple. Amino acid metabolism in adult rat skeletal muscle cells in tissue culture. I. Inhibition of branched chain amino acid metabolism by clofibric acid. Submitted for publication.

${ }^{4}$ Abbreviation used in this paper: $\mathrm{V}_{\max }$, maximum oxidation rate.
} 


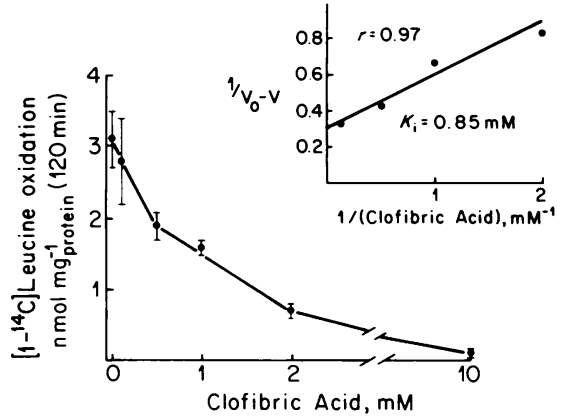

Figure 4 The conversion of $\left[1-{ }^{14} \mathrm{C}\right]$ leucine to ${ }^{14} \mathrm{CO}_{2}$ during a 2 -h incubation period is inhibited by increasing concentrations of clofibrate. The $K_{\mathrm{i}}$ (half-inhibition level) of clofibrate was calculated from the slope/intercept ratio of the double reciprocal plot; $V_{0}=$ rate of leucine oxidation in the absence of clofibrate; and $\mathrm{V}=$ rate of leucine oxidation at each respective dose of clofibrate. Data are mean \pm SEM $(n=4)$.

a concentration that approximates high therapeutic levels of the drug (23).

The effect of albumin, which actively binds clofibric acid (24), was also investigated. In these studies, the oxidation of $\left[1-{ }^{14} \mathrm{C}\right]$ leucine in the absence or presence of $3.0 \mathrm{~g} / 100 \mathrm{ml}$ albumin was $4.2 \pm 0.3 \mathrm{nmol} / \mathrm{mg}$ protein per $120 \mathrm{~min}$, and this was decreased to $1.2 \pm 0.2$ and $2.5 \pm 0.2 \mathrm{nmol} / \mathrm{mg}$ protein per $120 \mathrm{~min}$ by $2 \mathrm{mM}$ clofibric acid in the absence or presence, respectively, of 3.0 $\mathrm{g} / 100 \mathrm{ml}$ albumin. Therefore, a physiologic concentration of albumin did not abolish the effect of clofibrate, but did result in a $43 \%$ diminution in the inhibition of leucine oxidation caused by $2 \mathrm{mM}$ clofibrate.

To determine whether or not the inhibition of leucine transamination is associated with a decrease in the production of alanine by muscle, $\mathrm{L}_{6}$ cells were incubated for up to $4 \mathrm{~h}$ with clofibrate, and metabolite measurements were obtained at $1,2,3$ and $4 \mathrm{~h}$ of incubation. Cell protein in these studies averaged $2.3 \pm 0.2 \mathrm{mg}$ protein $/ 100-\mathrm{mm}$ dish. The metabolite data at 0 and $4 \mathrm{~h}$

TABLE II

Effect of Clofibric Acid (2 $\mathrm{mM}$ ) on Medium Metabolite Levels

\begin{tabular}{lccc}
\hline \multirow{2}{*}{ Metabolite } & $0 \mathrm{~h}$ & $4 \mathrm{~h}$ (control) & 4 (clofibrate) \\
\cline { 2 - 4 } & \multicolumn{3}{c}{$\mathrm{mM}$} \\
Glucose & $5.8 \pm 0.1$ & $5.3 \pm 0.1$ & $5.4 \pm 0.1$ \\
Lactate & $2.9 \pm 0.1$ & $3.4 \pm 0.1$ & $3.3 \pm 0.1$ \\
Pyruvate & $0.41 \pm 0.02$ & $0.21 \pm 0.02$ & $0.091 \pm 0.002 \ddagger$ \\
Lactate/pyruvate & $7 \pm 1$ & $16 \pm 1$ & $36 \pm 1 \ddagger$ \\
Alanine & $0.02 \pm 0.01$ & $0.12 \pm 0.01$ & $0.07 \pm 0.01 \ddagger$ \\
Glutamine & $0.52 \pm 0.01$ & $0.65 \pm 0.02$ & $0.69 \pm 0.04$ \\
\hline
\end{tabular}

* Mean \pm SE.I (three dishes measured in duplicate).

$\ddagger P<0.025$ difference from $4 \mathrm{~h}$ (control). are shown in Tables II and III. A 50\% decrease in net alanine production was observed in association with an increase in net pyruvate consumption. The onset of pyruvate consumption occurred after the block in branched chain amino acid utilization; e.g., at $1 \mathrm{~h}$ of incubation, when leucine oxidation was already inhibited (Fig. 1), there was no difference in medium pyruvate $(0.32 \pm 0.02 \mathrm{mM}$ control, $0.31 \pm 0.02 \mathrm{mM}$ treated). Relatively little change in medium glucose, lactate, or glutamine was observed in the treated cells (Table II). However, a significant increase in medium lactate/ pyruvate ratio was observed (Table II) in association with a decrease in cell aspartate (Table III). A similar inverse relationship between the medium lactate/pyruvate ratio and cell aspartate has been observed previously $(14,16)$. No significant differences in medium lactate/pyruvate ratio or cell aspartate were observed at 1 or $2 \mathrm{~h}$ of incubation; e.g., at $2 \mathrm{~h}$ the lactate/pyruvate ratio was $8 \pm 1$ in control cells and $9 \pm 1$ in treated cells, and the cell aspartate level was $5.3 \pm 0.3 \mathrm{nmol} / \mathrm{mg}$ protein in control cells and $5.9 \pm 0.5 \mathrm{nmol} / \mathrm{mg}$ protein in treated cells. In parallel to medium alanine, cell alanine was decreased in the drug-treated cells (Table III). No significant differences in glutamine, ATP, or Krebs cycle intermediates - malate, citrate, or $\alpha$-ketoglutarate-were observed in the clofibrate-treated cells (Table III). In addition, glycogen was not significantly different in the control $(16 \pm 1)$ vs. the treated $(13 \pm 2)$ cells after $4 \mathrm{~h}$ of incubation.

Clofibrate was not metabolized by the cells; the medium drug concentration was $1.9 \pm 0.1$ and $2.0 \pm 0.1$ $\mathrm{mM}$ at 0 and $4 \mathrm{~h}$ of incubation, respectively.

\section{DISCUSSION}

The present studies demonstrate that the acute administration of clofibrate to muscle cells results in a

TABLE III

Effects of Clofibric Acid (2 m.M) on Intracellular Metabolite Levels

\begin{tabular}{|c|c|c|c|}
\hline \multirow[b]{2}{*}{ Metabolite } & \multicolumn{3}{|c|}{ Incubation time* } \\
\hline & $\mathrm{Oh}$ & $4 \mathrm{~h}$ (control) & $4 \mathrm{~h}$ (clofibrate) \\
\hline & \multicolumn{3}{|c|}{ nmol/mg protein } \\
\hline Malate & $1.2 \pm 0.1$ & $1.6 \pm 0.2$ & $1.4 \pm 0.1$ \\
\hline Citrate & $2.5 \pm 0.1$ & $2.0 \pm 0.2$ & $1.5 \pm 0.2$ \\
\hline$\alpha$-Ketoglutarate & $1.3 \pm 0.2$ & $1.7 \pm 0.1$ & $1.9 \pm 0.2$ \\
\hline Aspartate & $5.7 \pm 0.2$ & $3.3 \pm 0.4$ & $1.2 \pm 0.2 \ddagger$ \\
\hline Alanine & $25 \pm 1$ & $6.5 \pm 0.7$ & $2.3 \pm 0.4 \ddagger$ \\
\hline Glutamate & $50 \pm 2$ & $22 \pm 2$ & $20 \pm 4$ \\
\hline Glutamine & $102 \pm 2$ & $42 \pm 5$ & $58 \pm 7$ \\
\hline ATP & $24 \pm 1$ & $26 \pm 1$ & $24 \pm 2$ \\
\hline
\end{tabular}

* Mean \pm SEM (three dishes measured in duplicate).

$\ddagger P<0.005$ difference from $4 \mathrm{~h}$ (control). 
rapid inhibition of branched chain amino acid oxidation. Other metabolic effects of clofibrate that may be secondary to the block in branched chain amino acid utilization are an increase in pyruvate consumption associated with a decrease in net alanine production, and a probable alteration in the NADH/NAD ${ }^{+}$redox state of the cytosol, as reflected by the medium lactate/pyruvate ratio. These latter two effects of acute clofibrate administration have also been observed in skeletal muscle cells obtained from adult rats and grown in primary tissue culture. ${ }^{3}$

The inhibition by clofibrate of the conversion of $\left[1-{ }^{14} \mathrm{C}\right]$ leucine to ${ }^{14} \mathrm{CO}_{2}$ might occur at one of at least four steps: (a) cell membrane transport of leucine; $(b)$ leucine transamination, which occurs primarily in the cytosol $(18) ;(c)$ transport of $\left[1-{ }^{14} \mathrm{C}\right]$ keto isocaproic acid from the cytosol into the mitochondria; and $(d)$ the $\alpha$-decarboxylation of the keto acid to $\mathrm{CO}_{2}$, which is mediated by the mitochondrial branched chain ketoacid dehydrogenase (18). An inhibition by clofibrate at steps $(a)$ or $(b)$ would be expected to inhibit the production of ${ }^{14} \mathrm{CO}_{2}$ in proportion to a decrease in ${ }^{14} \mathrm{C}$ keto-acid. Conversely, a block in steps $(c)$ or $(d)$ would be expected to decrease the ${ }^{14} \mathrm{CO}_{2}$ fraction to a greater extent than the ${ }^{14} \mathrm{C}$-keto-acid fraction. The data in Fig. 1 demonstrate that clofibrate selectively inhibits the production of $\mathrm{CO}_{2}$, not the $\alpha$-keto-acid of leucine. Therefore, it is likely that the drug is an inhibitor of the $\alpha$-decarboxylation of the branched chain keto-acids, although a site of action at a mitochondrial anion transport step cannot be excluded. The mechanism by which clofibric acid might inhibit the $\alpha$ decarboxylation of branched chain keto-acids could be either a direct or indirect action of the drug. Clofibrate possibly inhibits the branched chain keto acid dehydrogenase directly, via a noncompetitive mechanism (Fig. 3 ). Alternatively, the site of action of the drug might be at a distal step in the pathway of branched chain keto-acid oxidation; under these conditions the product of the $\alpha$-decarboxylation pathway (e.g., isovaleryl coenzyme A [CoA] in the case of the leucine pathway) would accumulate. Since the branched chain ketoacid dehydrogenase is subject to product inhibition (18), an accumulation of acyl CoA derivatives would be expected to inhibit the $\alpha$-decarboxylation of branched chain keto-acids. A similar sequence of events is believed to occur in rare forms of hypoglycemia caused by either inborn errors of metabolism or hypoglycin ingestion (25); in these conditions, a block in the metabolism of acyl CoA derivatives leads to an inhibition of both branched chain amino acid or free fatty acid metabolism. However, there is no apparent effect of acute clofibrate administration on free fatty acid oxidation in $\mathrm{L}_{6}$ muscle cells (see Results). The above two mechanisms of clofibrate action-direct and in- direct inhibition of dehydrogenase activity - might be distinguished by future studies in which isovaleryl CoA concentrations are measured after drug treatment.

Another mechanism by which clofibrate might inhibit branched chain amino acid oxidation is a drug-induced increase in the mitochondrial NADH/NAD ${ }^{+}$ ratio. Odessey and Goldberg (18) have shown that $\mathrm{NADH}$, an end-product of the branched chain keto acid dehydrogenase reaction, inhibits the enzyme. However, at least two observations argue against this mechanism of drug action. Firstly, the clofibrateinduced increase in lactate/pyruvate ratio, which is assumed to reflect the cytosolic $\mathrm{NADH} / \mathrm{NAD}^{+}$ratio, lags behind (see Results) the prompt reduction in leucine oxidation (Fig. 1). Secondly, if the drug did inhibit the dehydrogenase by raising the mitochondrial $\mathrm{NADH} / \mathrm{NAD}^{+}$ratio, then a similar inhibition of other mitochondrial dehydrogenases would be expected. However, the oxidation of alanine or lactate via pyruvate dehydrogenase or glutamate via $\alpha$-ketoglutarate dehydrogenase was not altered by clofibrate (Table I).

Finally, skeletal muscle appears to adapt to chronic clofibrate therapy. Paul and Adibi (3) have studied rats on $0.3 \mathrm{~g} / \mathrm{kg}$ per $\mathrm{d}$ of clofibrate for $3 \mathrm{wk}$, a dose that would be expected to achieve a plasma clofibrate level of about $1.5 \mathrm{mM}$ (17). Preliminary data indicate that the leucine oxidizing activity in gastrocnemius homogenate is increased $50 \%(26)$. Therefore, the level of the branched chain keto-acid dehydrogenase may possibly be induced under conditions of chronic drug inhibition so that the rate of branched chain amino acid oxidation is normalized. Further evidence that metabolic adaptations to chronic clofibrate treatment occur is the observation that the lactate/pyruvate ratio is normal in skeletal muscle of rats fed clofibrate for $3 \mathrm{wk}$ (27). Whether man is able to undergo similar adaptations to chronic clofibrate therapy is not known. Moreover, recent studies by Khatra et al. (28) indicate that skeletal muscle in man may be more dependent on the branched chain amino acids as carbon sources than that in the rat. The majority (76\%) of total body branched chain keto-acid dehydrogenase activity in the rat is in liver, whereas in man the majority $(62 \%)$ of total body dehydrogenase activity is in skeletal muscle. Therefore, it is possible that the extent to which skeletal muscle in man adapts to chronic clofibrate inhibition of branched chain amino acid oxidation is related in part to the development of myopathy.

\section{ACKNOWLEDGMENTS}

Charlotte Limberg provided excellent secretarial assistance. The authors are indebted to Dr. Mayer B. Davidson and Robert Karjala for performing the diaphragm incubations.

These studies were supported by National Institutes of Health grant AM-21762. 


\section{REFERENCES}

1. Langer, T., and R. I. Levy. 1968. Acute muscular syndrome associated with administration of clofibrate. $N$. Engl. J. Med. 279: 856-858.

2. Teravainen, H., A. Larsen, and M. Hillbom. 1977. Clofibrate-induced myopathy in the rat. Acta Neuropathol. 39: $135-138$.

3. Paul, H. S., and S. A. Adibi. 1979. Paradoxical effects of clofibrate on liver and muscle metabolism in rats. $J$. Clin. Invest. 64: 405-412.

4. Buse, M. G., and S. S. Reid. 1975. Leucine. A possible regulator of protein turnover in muscle. J. Clin. Invest. 56: $1250-1261$.

5. Wolfe, B. M., J. P. Kane, R. J. Havel, and H. P. Brewster. 1973. Mechanism of the hypolipemic effect of clofibrate in postabsorptive man. J. Clin. Invest. 52: 2146-2159.

6. Felig, P. 1975. Amino acid metabolism in man. Annu. Rev. Biochem. 44: 933-955.

7. Ruderman, N. B., and M. Berger. 1974. The formation of glutamine and alanine in skeletal muscle. J. Biol. Chem. 249: 5500-5506.

8. Garber, A. J., I. E. Karl, and D. M. Kipnis. 1976. Alanine and glutamine synthesis and release from skeletal muscle. I. Glycolysis and amino acid release. J. Biol. Chem. 251: 826-835.

9. Lee, S-H., and E. J. Davis. 1979. Carboxylation and decarboxylation reactions. Anaplerotic flux and removal of citrate cycle intermediates in skeletal muscle. J. Biol. Chem. 254: 420-430.

10. Odessey, R., E. A. Khairallah, and A. L. Goldberg. 1974. Origin and possible significance of alanine production by skeletal muscle. J. Biol. Chem. 249: 7623-7629.

11. Wahren, J., P. Felig, and L. Hagenfeldt. 1976. Effect of protein ingestion on splanchnic and leg metabolism in normal man and in patients with diabetes mellitus. $J$. Clin. Invest. 57: 987-999.

12. Pardridge, W. M., M. B. Davidson, and D. CasanelloErtl. 1978. Glucose and amino acid metabolism in an established line of skeletal muscle cells. J. Cell. Physiol. 96: $309-318$.

13. Pardridge, W. M., and M. B. Davidson. 1979. Alanine metabolism in skeletal muscle in tissue culture. Biochim. Biophys. Acta. 34-42.

14. Pardridge, W. M., L. Duducgian-Vartavarian, D. Casanello-Ertl, M. R. Jones, and J. D. Kopple. 1980. Glucose and amino acid metabolism in neonatal rat skeletal muscle in tissue culture. J. Cell. Physiol. 102 : 91-98.

15. Yaffe, D. 1973. Rat skeletal muscle cells. In Tissue Cul-
ture-Methods and Applications. P. Kruse and M. K. Patterson, editors. 106-114.

16. Pardridge, W. M., and D. Casanello-Ertl. 1979. Effects of glutamine deprivation on glucose and amino acid metabolism in tissue culture. Am. J. Physiol. 236: E234-E238.

17. Barrett, A. M., and J. M. Thorp. 1968. Studies on the mode of action of clofibrate: effects on hormone-induced changes in plasma free fatty acids, cholesterol, phospholipids and total esterified fatty acids in rats and dogs. Br. J. Pharmacol. Chemother. 32: 381-391.

18. Odessey, R., and A. L. Goldberg. 1979. Leucine degradation in cell-free extracts of skeletal muscle. Biochem. J. 178: 475-489.

19. Hutson, S. M., T. C. Cree, and A. E. Harper. 1978. Regulation of leucine and $\alpha$-ketoisocaproate metabolism in skeletal muscle. J. Biol. Chem. 253: 8126-8133.

20. Chen, T. R. 1977. In situ detection of mycoplasma contamination in cell cultures by fluorescent Hoechst 33258 stain. Exp. Cell Res. 104: 255-262.

21. Schneider, E. L., E. J. Stanbridge, and C. J. Epstein. 1974. Incorporation of ${ }^{3} \mathrm{H}$-uridine and ${ }^{3} \mathrm{H}$-uracil into RNA. A simple technique for the detection of mycoplasma contamination of cultured cells. Exp. Cell Res. 84: 311-318.

22. Goldberg, A. L., and R. Odessey. 1972. Oxidation of amino acids by diaphragms from fed and fasted rats. Am. J. Physiol. 223: 1384-1391.

23. Houin, G., J. J. Thebault, Ph. d'Athis, J-P. Tillement, and J-L. Beaumont. 1975. A GLC method for estimation of chlorophenoxyisobutyric acid in plasma. Pharmacokinetics of a single oral dose of clofibrate in man. Eur.J. Clin. Pharmacol. 8: 433-437.

24. Spector, A. A., and E. C. Santos. 1973. Influence of free fatty acid concentration on drug binding to plasma albumin. Ann. N. Y. Acad. Sci. 226: 247-258.

25. Dusheiko, G., M. C. Kew, B. I. Joffe, J. R. Lewin, F. F. Path, S. Mantagos, and K. Tanaka. 1979. Recurrent hypoglycemia associated with glutaric aciduria type II in an adult. N. Engl. J. Med. 201: 1405-1409.

26. Paul, H. S., and S. A. Adibi. 1978. Muscle oxidation of leucine when glucose and fatty acid oxidation are impaired. Fed. Proc. 37: 541 (Abstr.).

27. Wilkening, J., F. Wolpert, and P. Schwandt. 1977. Glycolytic metabolites and adenosine triphosphate in skeletal and cardiac muscle of rats after clofibrate feeding. Biochem. Pharmacol. 27: 244-245.

28. Khatra, B. S., R. K. Chawla, C. W. Sewell, and D. Rudman. 1977. Distribution of branched-chain $\alpha$-keto acid dehydrogenases in primate tissues. J. Clin. Invest. 59: $558-564$. 